\title{
Analysis of Microbial Communities in Aquatic Sediment Microbial Fuel Cells Injected with Glucose
}

\author{
Min Kim ${ }^{1}$, Kalu I. Ekpeghere ${ }^{2}$, Soo-Hyeon Kim ${ }^{2}$, Jae-Soo Chang ${ }^{2}$, and Sung-Cheol Koh ${ }^{2 *}$ \\ ${ }^{1}$ Chumgshim International High School, Gapyeong 477-855, Republic of Korea \\ ${ }^{2}$ Department of Environmental Engineering, Korea Maritime University, Busan 606-791, Republic of Korea

\section{포도당을 주입한 수중퇴적물을 이용한 연료전지시스템에 있어서 미생물군집 분석}

\author{
김 민 ${ }^{1} \cdot$ Kalu I. Ekpeghere ${ }^{2} \cdot$ 김수현 $^{2} \cdot$ 장재수 $^{2} \cdot$ 고성철 ${ }^{2 *}$ \\ ${ }^{1}$ 청심국제고등학교 \\ ${ }^{2}$ 한국해양대학교 환경공학과
}

(Received December 12, 2012 / Accepted December 26, 2012)

\begin{abstract}
The purpose of this research was to optimize electric current production of sediment microbial fuel cells by injecting glucose and to investigate its impact on microbial communities involved. It was shown that injection of proper concentration of glucose could increase electric current generated from sediment microbial fuel cells. When 1,000 $\mathrm{mg} / \mathrm{L}$ of glucose, as opposed to higher concentrations, was injected, electric current increased up to 3 times. This increase is mainly attributed to the mutual relationship between fermenting bacteria and exoelectrogenic bacteria. Here the organic acids generated by fermenting bacteria could be utilized by exoelectrogenic bacteria, removing feedback inhibition caused by the organic acids. When glucose was injected, the population of Clostridium increased as to ferment injected glucose. Glucose fermentation can have either a positive or negative effect on electric current generation. When exoelectrogenic bacteria may readily utilize the end-product, electric current could increase. However, when the end-product was not readily removed, then detrimental chemical reactions ( $\mathrm{pH}$ decrease, methane generation, organic acids accumulation) occurred: exoelctrogenic bacteria population declined and non-microbial fuel cell related microorganisms prospered. By injecting a proper concentration of glucose, a mutual relationship between fermenting bacteria, such as Clostridium, and exoelectrogenic bacteria, such as Geobacter, should be fulfilled in order to increase electricity production in mixed cultures of microorganisms collected from the aquatic sediments.
\end{abstract}

Keywords: Clostridium sp., exoelectrogenesis, fermentation, sediment microbial fuel cells (SMFC)

Sediment Microbial fuel cell (SMFC) allows utilization of organic matter present in aquatic sediment to produce electricity. SMFC has many advantages. First, it is environmentally friendly. Second, it is able to use the organic material already present in the sediment as carbon source. Finally, it is able to produce electricity for a relatively long period (Song et al., 2011). However, the main problem associated with SMFC is that the power density is relatively low due to limited organic content in the aquatic sediment. To increase electric current produced from SMFC, certain organic substrates have to be

*For correspondence. E-mail: skoh@hhu.ac.kr; Tel.: +82-51-410-4418; Fax: +82-51-410-4415 added to the sediment (Rezaei et al., 2007; Pant et al., 2009).

Organic content fermentation in a mixed bacteria culture can be very complex and is related to metabolism of different microorganisms (Kiely et al., 2011). Clostridium sp. (Park et al., 2011) and Geobacter sulfurreducens (Lovely et al., 1993) were found to be the two most dominant bacteria in a culture fed with glucose (He et al., 2007). Fermenting bacteria initially ferments glucose to acetate. Then, exoelectrogenic bacteria can readily consume acetate, removing feedback inhibition and stimulating more fermentation. Fermenting bacteria need exoelectrogenic bacteria in order to maintain the product concentration low (He et al., 2007). This mutual relationship, if stimulated, can enhance electric current produced. However, if 
exoelectrogenic bacteria do not readily consume the fermentation by product, organic acid accumulation and methane production can occur (Moon et al., 2006; Freguia et al., 2008).

More complex fermentation occurs when the loading of glucose becomes excess. High loading of glucose results in mixed organic acid generation and methane generation. Fermentation from glucose to mixed organic acids such as butyric acid lowers the $\mathrm{pH}$ of the sediment and interrupts electricity generation. Moreover, Excess hydrogen ions that cannot be oxidized by exoelectrogenic bacteria are then used up by other microorganisms including methanogens (Hong et al., 2004). As a result, Methane lowers the columbic efficiency of fuel cells, as reported by other researchers (Freguia et al., 2008; Kiely et al., 2011).

Two stages of glucose fermentation exist. The first stage is called the acidogenic period, which ferments glucose to acetate and butyrate. This period lowers the $\mathrm{pH}$ by generating organic acids. When organic acids continuously accumulate and are not removed, second stage fermentation occurs. The second stage is called the solventogenic period, which is responsible for the fermentation of acetate and butyrate to acetone and butanol. When ethanol or butanol is produced, cell growth is inhibited. Thus, when organic acids accumulate and proceed to solventogenic period, electricity generation can be significantly reduced (Chin et al., 2003).

Considering that the metabolism of exoelectorgenic bacteria is highly dependent on hydrogen production from organic material, one way to increase the current of sediment microbial fuel cells is to inject organic material (Logan, 2009). The main purpose of this research is to optimize electric current production of sediment concentration fuel cells by injecting glucose. The optimal concentration of glucose that can stimulate electricity generation as well as its impact on microbial communities was investigated. Understanding and analyzing the microbial community will improve the electricity generation as well as potential usage of sediment microbial fuel cell.

\section{Materials and Methods}

\section{Construction of microbial fuel cell system}

Aquatic sediment from Ulwangli Sea $\left(37^{\circ} 26^{\prime} 52^{\prime \prime} \mathrm{N}, 126^{\circ} 22^{\prime}\right.$ $\left.16^{\prime \prime} \mathrm{E}\right)$ and Han River $\left(37^{\circ} 31^{\prime} 59^{\prime \prime} \mathrm{N}, 126^{\circ} 54^{\prime} 25^{\prime \prime} \mathrm{E}\right)$ were collected. After the collection, the muds were kept at $-4^{\circ} \mathrm{C}$ in the iceboxprior to the experiment. Water from both Ulwangli Sea and Han River was collected to be used in cathode compartment.

Microbial fuel cells were constructed with sediments collected. Two electrodes $(2 \mathrm{~cm} \times 2 \mathrm{~cm}$ TGP-H $09020 \mathrm{wt} \%$ Wet Proofing, Toray, Japan) were connected to the copper wire with elastic bands (4.0 $\mathrm{mm}$ diameter) in both anode and cathode; Two electrodes were piled. One electrode was sampled during the mid-phase of the experiment, while the other was collected at the end of the experiment. Anode and Cathode compartments (200 ml plastic container with a plastic cap) were connected with PVC joint (16A) functioning as proton exchange membrane (mixture of agar powder, salt, and water). A $2 \mathrm{~cm}$ radius hole was made on each plastic container to connect to the PVC joint. Oxygen was constantly supplied to the cathode compartment with oxygen pump (DK-200, DaeKwang, Korea). In order to make the water level in Cathode compartment constant, salt water and fresh water collected was daily filled to compensate for the water loss by evaporation.

Four identical SMFCs were constructed. The copper wire in Cathode was connected to that in Anode with electrical cables connected to the Data Acquisition Device (USB 6008, National Instrument, USA). Labview 2011 was used to collect the electric current data every $100 \mathrm{sec}$ and saved it to a personal computer (external resistance set to $249 \mathrm{ohm}$ ).

\section{Microbial fuel cell operation}

Total of four microbial fuel cells were constructed. Two were based on salt water sediment; other two were based on fresh water sediment. 5,000 mg/L of glucose solution (Glucose Monohydrate $50 \%$ solution, Dai Han Pharm, Korea) was injected to each one of the two types SMFCs. Each of the other SMFCs was remained as a control group. In the process of glucose injection, the anode compartment was opened and glucose solution was poured on the top of the mud, and the anode compartment was closed right after glucose injection. The current was monitored for a total of 30 days (glucose injection on Day 12). All the electrodes (both before glucose injection and after the experiment) and the soil samples were collected and kept in the laboratory freezer prior to DNA analysis and chemical analysis. Additional experiment was conducted by varying the concentration of glucose injected to the sediment. Total of eight microbial fuel cells were constructed: four based on salt water sediment and the other four based on fresh water sediment. For each type of SMFCs, 0 $\mathrm{mg} / \mathrm{L}, 1,000 \mathrm{mg} / \mathrm{L}, 5,000 \mathrm{mg} / \mathrm{L}$, and $10,000 \mathrm{mg} / \mathrm{L}$ of glucose solution was injected, and the electric current was monitored for total of 10 days.

\section{DNA extraction and microbial community analysis by PCR-DGGE}

Mud on the electrode was scraped with sterile blade and DNA extraction kit (Fast DNA SPIN Kit for Soil, MPBio, USA) was used to extract the DNA from the soil. All the experiment procedures were followed exactly by the protocols given by the MPBio. After a small amount of DNA from total of 8 samples 
were extracted according to the standard PCR protocols (Vernon Coyne, 2001) with little modifications in reaction agents offered by Solgent (DE16-R250, Solgent, Korea). 16S PCR (1492-R, 27-F) and nested PCR (NPCR) (786-R, 341F-GC) were conducted according to the standard PCR protocols. DNA Reader (Kodak edas 290 1kb DNA Reader, SolGent) was used to determine whether 16S PCR was conducted successfully and ready for the NPCR.

With the product from NPCR, DGGE (D Code Universal Mutation Detection System, Bio-Rad, USA) was done and each gel was eluted. A small amount of gel was extracted and Fragment PCR (786-R, 341-F) was done to amplify the DNA cut out from each gel. The amplified DNA was cloned according to the protocol and two samples were made for each clone to ensure the DNA identity analysis results are confidential (Schumahcer, 2002). Cloning PCR (M13-F, M13-R) was done and the products of Colony PCR were sent to Solgent Korea for DNA identification.

\section{Chemical analysis}

Gas chromatography was carried out for the samples using Agilent GC 6890 machine (Hewlett-Packard, USA). The samples were pretreated with sulfuric acid, and the organic acids were dissolved using $4 \mathrm{ml}$ of diethyl ether. After centrifuging, the dissolved compound was filtered with anhydrous sodium sulfate. GC was run for $10 \mathrm{~min}$ and the target acids included acetic, propionic, isobutyric, butyric, isovaleric, valeric, isocaponic, caponic, and lactic acid. TOC analyzer was used to measure the total organic carbon in the soil. The measurement of TOC was followed by methods proposed by Brian A. Schumacher (Schumahcer, 2002). pH of the samples was measured using a pH meter (pH-200L, ISTEK, Korea).

\section{Results and Discussion}

\section{Electricity generated from aquatic mud based fuel cells}

Electricity generation from microbial fuel cell based on salt-water sediment had a maximum current of about $0.11 \mathrm{~mA}$. It took about 4 days to reach the maximum current of $0.11 \mathrm{~mA}$ from almost $0 \mathrm{~mA}$. On about Day 5, the current stabilized to $0.08 \mathrm{~mA}$. After the $5,000 \mathrm{mg} / \mathrm{L}$ of glucose injection, the current reached its peak value of $0.09 \mathrm{~mA}$ after about $12 \mathrm{~h}$ and decreased significantly to about $0.01 \mathrm{~mA}$. On the other hand, after one electrode was removed from the anode compartment, the control group slowly recovered its previous current of about $0.1 \mathrm{~mA}$ after about 3 days. It can be inferred that $5,000 \mathrm{mg} / \mathrm{L}$ of glucose was excess for the sediment to dissolve because electric current decreased significantly almost to zero after glucose injection (Fig. 1A).

The maximum current that can be generated from fresh water sediment was about $0.15 \mathrm{~mA}$. It took about 4 days for the electricity generation to stablize to about $0.15 \mathrm{~mA}$ from initial current of $0.11 \mathrm{~mA}$. When $5,000 \mathrm{mg} / \mathrm{L}$ of glucose was injected, the current reached its peak of about $0.15 \mathrm{~mA}$ within one and a half day. One day after the current reached its peak, the electric current generated from fuel cell injected with glucose became similar to that generated from a control group. However, from Day 27 of the experiment, the current from control group decreased while that from glucose injected group stayed high. The current after glucose injection can be summarized to one small peak followed by a increase in current, but there was no significant increase in electric current (Fig. 1B).

Microbial fuel cells based on fresh water sediment and
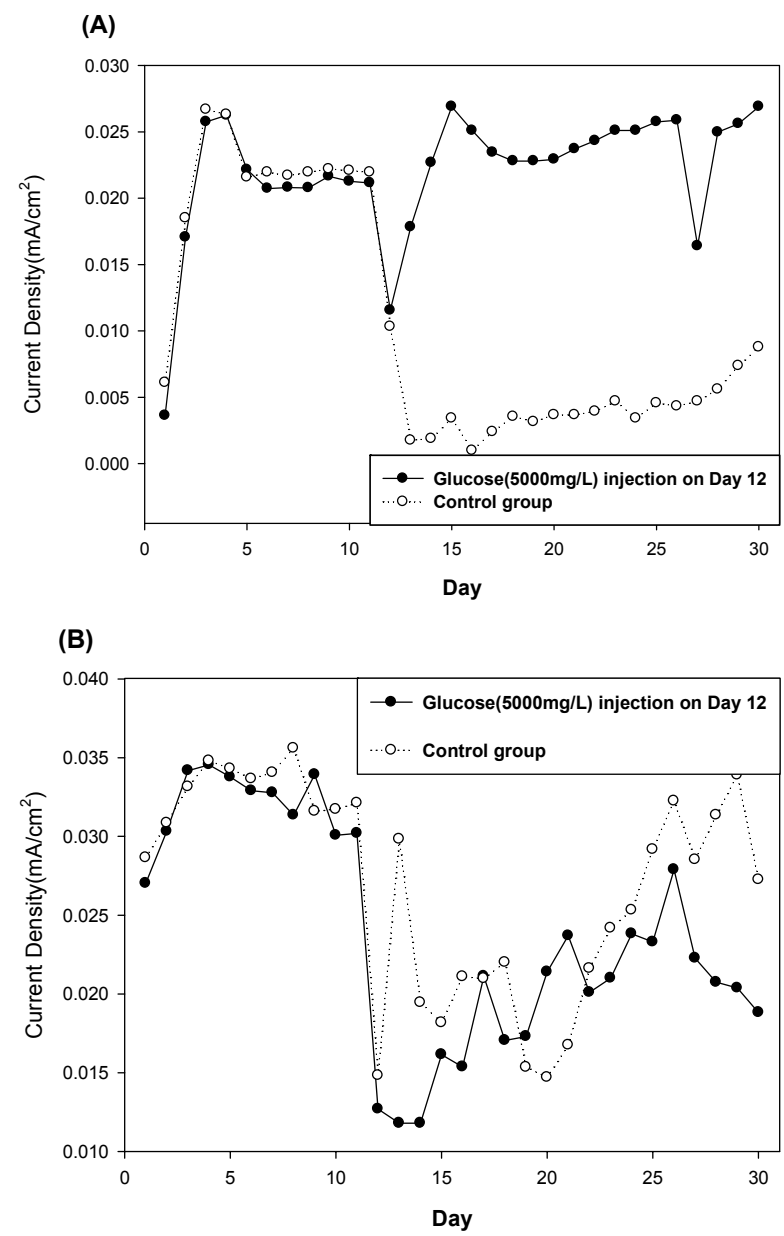

Fig. 1. (A) Electric current generation from salt water sediment. (B) Electric current generation from fresh water sediment. Electric current was measured for 30 days, and $5,000 \mathrm{mg} / \mathrm{L}$ of glucose was injected to sediment on Day 12. One microbial fuel cell was each remained as a control group. The decrease in electric current on Day 12 is due to collection of one electrode from anode department, interrupting electiricy generation. 
Table 1. Organic acids that were detected in the sediment collected from anode compartment of fuel cells*

\begin{tabular}{ccc}
\hline $\begin{array}{c}\text { Type of } \\
\text { organic acid }\end{array}$ & $\begin{array}{c}\text { Concentration of organic acids }(\mathrm{mg} / \mathrm{L}) \text { from salt water } \\
\text { sediment treated with glucose }\end{array}$ & $\begin{array}{c}\text { Concentration of organic acids }(\mathrm{mg} / \mathrm{L}) \\
\text { fresh water sediment treated with glucose }\end{array}$ \\
\hline Acetic acid & 104.72 & 367.85 \\
Propionic acid & 63.12 & 68.64 \\
Isoburytic acid & 69.92 & 0 \\
Burytic acid & 1193.67 & 421.78 \\
Caponic acid & 66.7 & 0 \\
\hline
\end{tabular}

*Concentration of organic acids found on Day 30 from salt water sediment or fresh water sediment treated with glucose (5,000 mg/L)

salt-water sediment reacted oppositely to glucose injection. Electric current was slightly increased after glucose injection in the case of fresh water sediment while it decreased dramatically in the case of salt-water sediment. It seems that the glucose utilizing ability by microbial fuel cell related microorganisms of fresh water sediment is higher than that of salt-water sediment.

\section{Organic acids measurements}

Organic acids were only found in sediments that were treated with glucose. This shows that the organic acids were by-product of glucose fermentation. High butyric acid content in glucose treated fresh water sediment indicates that the glucose loading was excess and that the exoelectrogenic bacteria could not readily consume the butyric acid. High butyric acid would have led to high toxicity (Chin et al., 2003) (Table 1). Moreover, high butryric acid content will lead to second stage fermentation, in which acetone and butanol is generated. Further analysis of such compounds would indicate how far the second stage fermentation had passed (Chin et al., 2003). The second stage fermentation is detrimental to electric current generation and can attribute to electric current decrease in microbial fuel cells. Overall, rganic acids measurement have shown that the glucose loading was too high and that the sediments have gone through accumulation of organic acids, which made the survival of exoelectrogenic bacteria more harsh. Moreover, high butyric acid suggests high toxicity and methane generation, which considerably hinders the Columbic efficiency (Chin et al., 2003; Kiely et al., 2011).

\section{Total organic carbon (TOC)}

For the control group, to which glucose was not injected, the TOC value decreased from Day 12 to Day 30. This decrease is probably attributed to the microbial activity of electricity generating bacteria which oxidizes organic compound. The TOC decreased about $0.278 \%$ during 18 days in fresh water sediment, and it decreased about $0.088 \%$ during 18 days in salt-water sediment. These results show that the salt water sediment, although initially low on organic carbon, can use relatively small amount of carbon to generate electricity than fresh water sediment (Table 2). Initially low organic carbon in salt water sediment is attributed to the texture of the sand. Fresh water sediment had a mud-like texture which has an ability to store high amount of nutrient, but fresh water sediment had sand-like texture which hinders much nutrient to be stored. When glucose was injected, the TOC of injected group on Day 30 was higher than that of control group on Day 12. Although the microorganisms have used organic carbon during their metabolic process, glucose has provided the sediment with additional carbon source. This resulted in overall increase in organic carbon. This shows the effectiveness of glucose as carbon source for sustanenece of microorganisms.

\section{SEM views of the fuel cell electrodes}

Compared to the control groups, sediments for both fresh water and salt water after glucose $(5,000 \mathrm{mg} / \mathrm{L})$ injection showed sign of fermentation as well as methane generation. The color of the sediment became dark brown. For fresh water sediment, more methane seemed to have generated considering the bubbles on the surface as well as the darker color of the

Table 2. Total organic carbon (TOC) measured in aquatic sediments injected with glucose $(5,000 \mathrm{mg} / \mathrm{L})$

\begin{tabular}{ccc}
\hline $\begin{array}{c}\text { Type of } \\
\text { aquatic sediment }\end{array}$ & $\begin{array}{c}\text { Average total organic } \\
\text { carbon on Day 12 (\%) }\end{array}$ & $\begin{array}{c}\text { Average total organic } \\
\text { carbon on Day 30 (\%) }\end{array}$ \\
\hline Fresh Water Sediment without glucose (control) & 2.165 & 1.887 \\
Fresh Water Sediment injected with glucose & 1.683 & 1.885 \\
Salt Water Sediment without glucose (control) & 0.083 & 0 \\
Salt Water Sediment injected with glucose & 0.03 & 0.099 \\
\hline
\end{tabular}



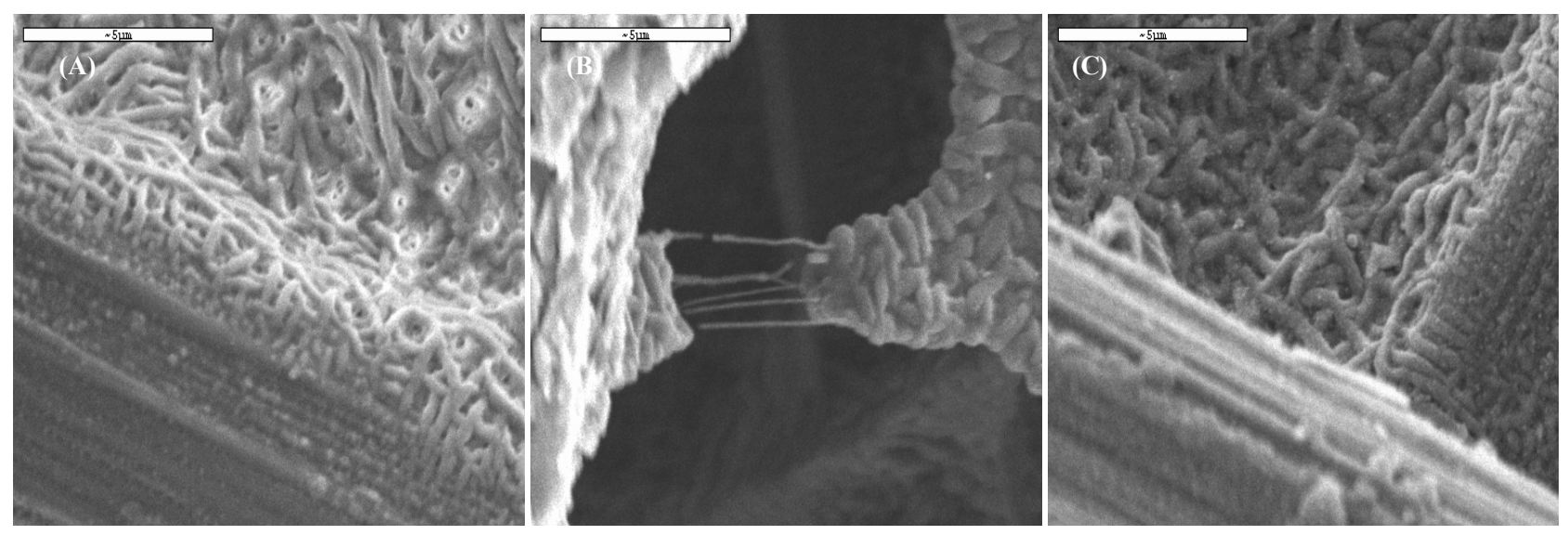

Fig. 2. SEM picture of the electrode of SMFC based on fresh water sediment. (A) Fresh water sediment electrode on Day 12. (B) Fresh water sediment electrode on Day 30 (control). (C) Fresh water sediment electrode on Day 30 (glucose injected).

sediment. SEM pictures of the fresh water sediment electrode shows that there is presence of anodophile bacteria. They also show the presence of interaction among anodophile bacteria. Without glucose injection on Day 12, SEM picture showed abundunce of bacteria on the anode surface. However, after glucose injection, the population of anodophile bacteria seem to have decreased. Increased electricity generation after glucose injection, with decrease in anodophile bacteria, might be explained by metabolism of exoelectrogenic bacteria that are capable of glucose fermentation rather than anodophile bacteria (Freguia et al., 2008) (Fig. 2).

SEM pictures of saltwater sediment electrode showed anodophile bacteria that interact with each other. However, after the glucose injection, SEM picture of the electrode showed that the glucose injection had a detrimental effect on anodophile bacteria community. Indeed, the SEM picture showed sign of the apparent dead bacteria on the electrode surface. The population of anodophile bacteria was significantly lower compared to that of fresh water sediment electrode after glucose injection. These apparent dead cells on the electrode surface after glucose injection explain why the current was suddenly dropped after glucose injection (Fig. 3).

\section{Microbial community analysis in the fuel cell system}

Exoelectrogenic microorganisms found in the electrodes were Clostridium, Geobacter, Pseudomonas, Rhodoferax, and Desulfobacteraceae family (Bond and Lovley, 2003; Holmes et al., 2004). The most dominant type of microorganism related to microbial fuel cell was Clostridium. The microbial community analysis corresponds with the electric current data. The electrode collected on Day 12 from fresh water sediment contained no other electricity generating microorganisms than Clostridium. Also, Clostridium was one of the most dominant species (Band 7, 99\% identity) in the microbial community in fresh water sediment (Fig. 4). It can be predicted that the electric current generated from SMFC based on fresh water
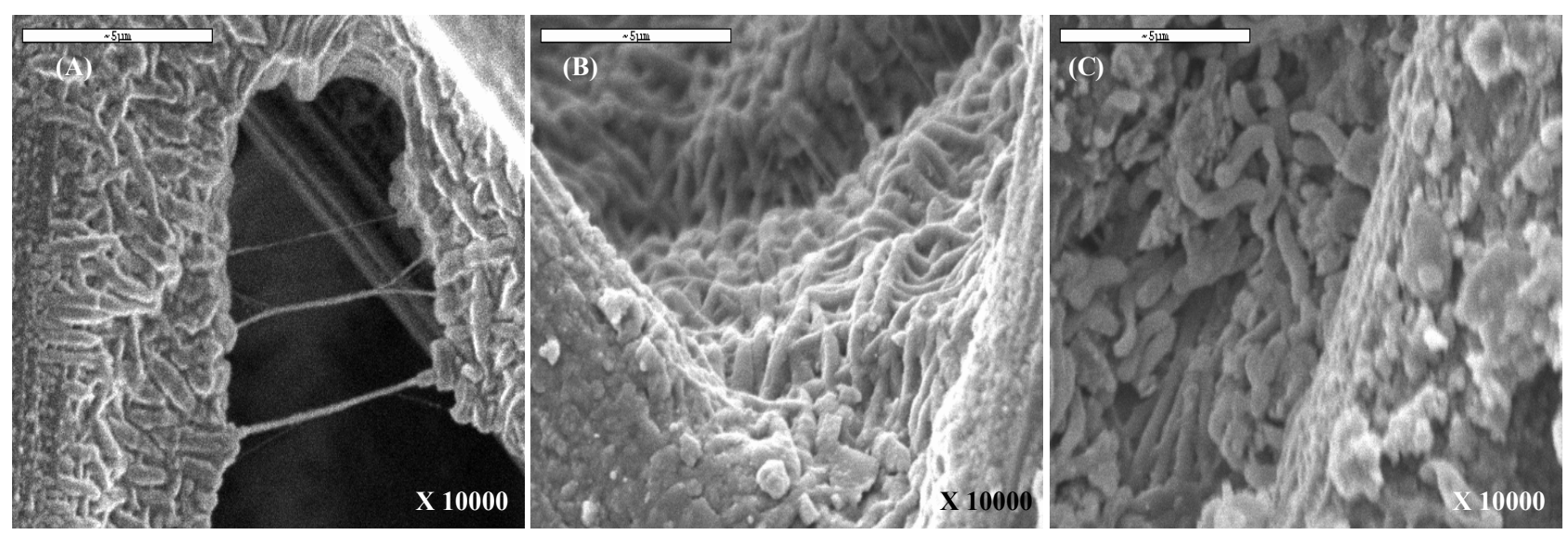

Fig. 3. SEM picture of the electrode of SMFC based on salt water sediment. (A) Salt water sediment electrode on Day 12. (B) Salt water sediment electrode on Day 30 (control). (C) Salt water sediment electrode on Day 30 (glucose injected). 
sediment before glucose injection was mainly from Clostridium species fermenting organic carbon already present in the sediment, with the absence of dominant exoelectrogenic bacteria (Rabaey et al., 2003).

After glucose injection on Day 12, microbial community changed drastically. In fresh water sediment, population of fermenting microorganisms and iron reducing microorganism increased. The control group that was not injected glucose developed sulfate reducing bacterium (Band 25, 97\% identity), and Rhodoferax (Band 26, 99\% identity), which are electrochemically active. In glucose injected group in fresh water sediment, although iron reducing bacterium (Band 32, 99\% identity), and Pseudomonas (Band 27, 99\% identity) were present on the surface of the electrode, population of Clostridium or related species (Band 28, 29, 30, 31, 33, 34) far outweigh that of microorganisms that directly generate electricity (Logan et al., 2005) (Fig. 4). These results show that the mutual relationship between fermenting bacteria and

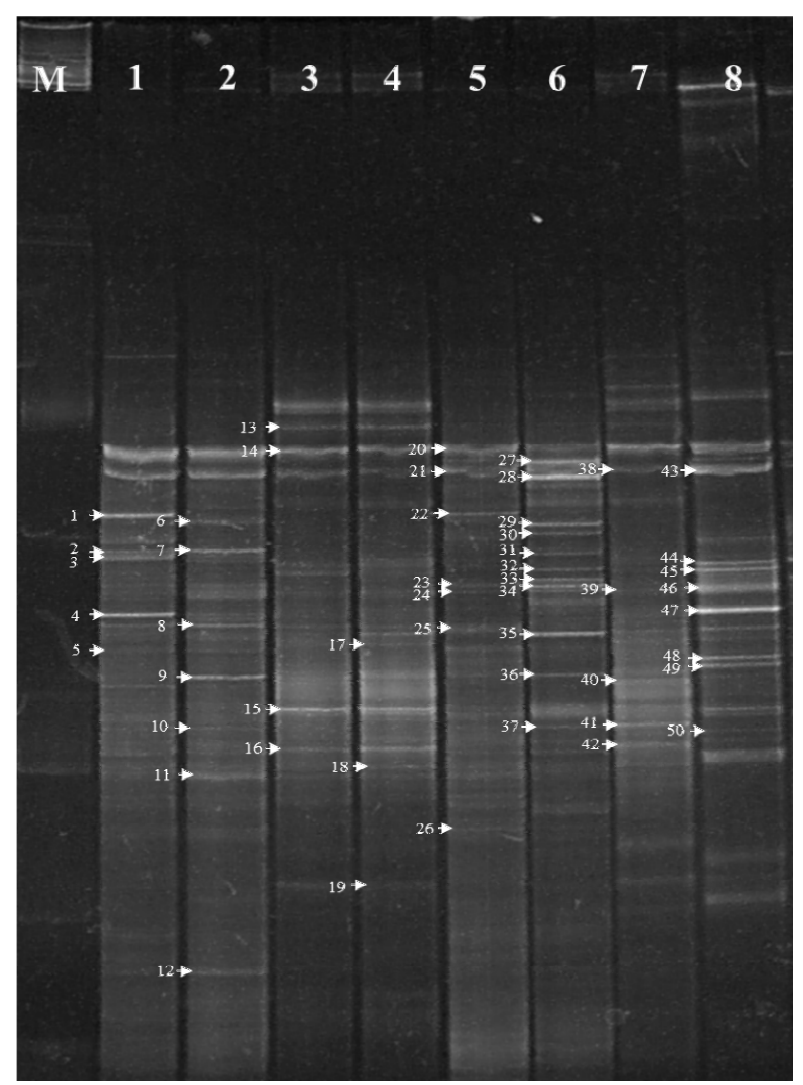

Fig. 4. PCR-DGGE profiles of the sediment microbial communities scraped from anode electrodes (Lanes: 1-2, Fresh water sediment electrode on Day 12; 3-4, Salt water sediment electrode on Day 12; 5, Fresh water sediment electrode on Day 30 (control); 6, Fresh water sediment electrode on Day 30 (glucose injected); 7, Salt water sediment electrode on Day 30 (control); 8, Salt water sediment electrode on Day 30 (glucose injected). bacteria seeking to directly convert organic content to electricity is unbalanced. An overload of glucose, $5,000 \mathrm{mg} / \mathrm{L}$, made the fermenting bacteria prosper, but exoelectrogenic bacteria were not able to consume the by-product of fermentation as fast as it was produced, leading to only a slight increase in electric current production.

Unbalance in population of fermenting bacteria and exoelectrogenic bacteria led to accumulation of mixed organic acids and methane. Decrease in $\mathrm{pH}$ as well as methane production lowers the ability of electricity generating microorganisms. All in all, it can be concluded from the microbial data that the glucose load was too high for fresh water sediment to efficiently generate electricity (Finch et al., 2011).

In the SMFC based on salt-water sediment on Day 12, no significant population of electricity generating microorganisms was found. Desulfobulbaceae (Band 18, 99\% identity), sulfur-reducing family, was found and it seemed that this bacterium was partly involved in the electricity generation process (Fig. 4). The total community of bacteria dedicated to electricity generation in salt water was smaller than that in fresh water.

In salt-water sediment, fermenting bacteria Clostridium developed after glucose injection, but its population was not dominant like that in fresh water. Thus, other bacteria unrelated to electricity generation developed and prospered. Bacterium like Marinobacterium (Band 47, identity 98\%) and Rhodobacteraceae (Band 43, 46, Identity 99\%), which are opportunistic and heterotopic, developed after the glucose injection (Fig. 4). Possible explanation for this phenomenon is that the glucose load was too high that the fermenting bacteria in salt-water sediment could not degrade the glucose, which led to population boom of non-specific bacteria unrelated to electricity generation. Moreover, some glucose was degrade by Clostridium, but anodophile bacteria due to lowered $\mathrm{pH}$ as well as methane production could not consume the by-product. The overall conditions in glucose injected group made the bacteria living on the anode surface to suffer from methane generation and lowered $\mathrm{pH}$ as well as decrease in carbon source consumed by opportunistic microorganisms (Chin et al., 2003).

\section{Electricity generated from injection of different concentrations of glucose}

In the case of microbial fuel cells based on fresh water sediment, when $10,000 \mathrm{mg} / \mathrm{L}$ of glucose was added, the current remained similar to that of control group. However, when $1,000 \mathrm{mg} / \mathrm{L}$ of glucose was added to the fresh water, it took abot two and a half day to reach the peak current of about 0.16 $\mathrm{mA}$, which is significantly higher. The current stayed high for 
about 4 days. This experiment shows that the right amount of glucose added to the fresh water sediment microbial fuel cell can stimulate mutual relationship among fermenting bacteria and electricity generating bacteria to improve the electricity generation (Fig. 5).

In the case of microbial fuel cells based on salt-water sediment, when $10,000 \mathrm{mg} / \mathrm{L}$ of glucose was added, the current dropped to almost zero. This indicates that the glucose molarity was too high that the overall environment became harsh for anodophile bacteria due to methane generation and decrease in $\mathrm{pH}$ as well as emergence of other opportunistic microorganisms. On the other hand, when $1,000 \mathrm{mg} / \mathrm{L}$ of glucose was injected, the current reached its peak of about $0.15 \mathrm{~mA}$ in about 4 days and remained high for at least more than 4 days. This also shows that the proper loading of glucose to sediment microbial fuel cells can improve the current more than three times (Fig. 6). For both salt-water sediment and fresh water sediment,

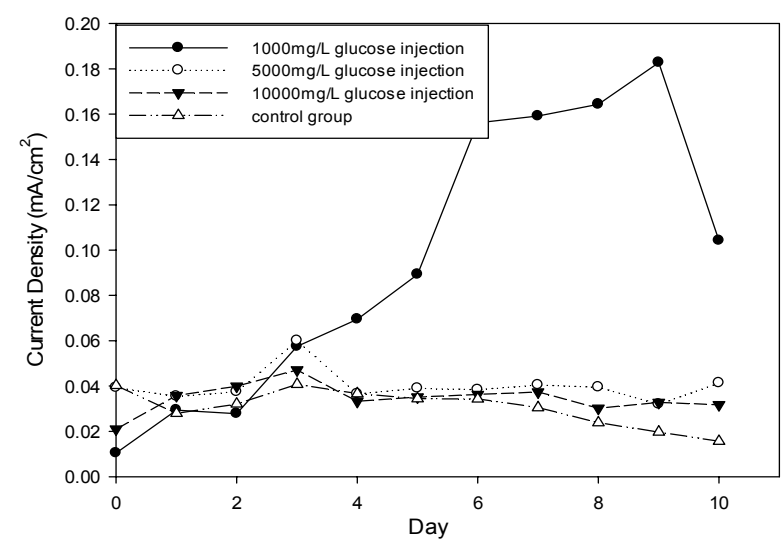

Fig. 5. Current generation of microbial fuel cells based on fresh water sediment with injection of different concentrations of glucose, which was added on Day 2. Electric current was measured for 10 days.

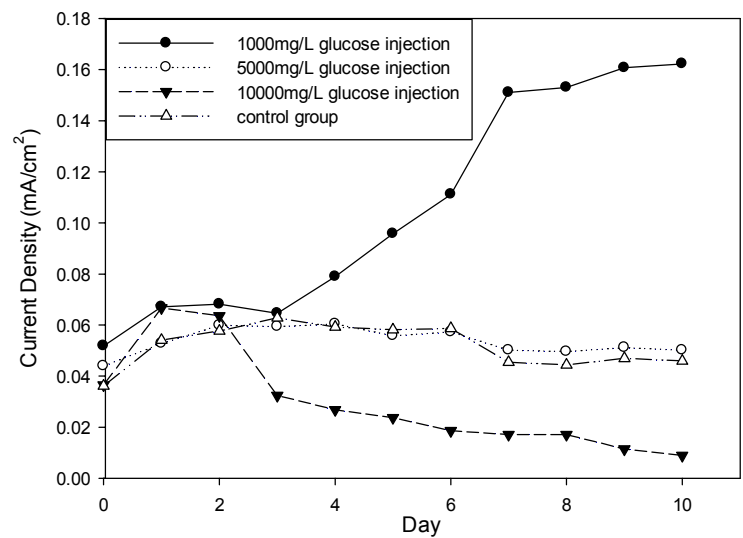

Fig. 6. Current generation of Microbial fuel cells based on salt water sediment with injection of different concentrations of glucose, which was added on Day 2. Electric current was measured for 10 days.
$1,000 \mathrm{mg} / \mathrm{L}$, although the lowest in concentration, was found to be the proper amount that can increase electric current.

\section{Relationship between $\mathrm{pH}$ and concentration of glucose injected}

Injected glucose concentration and $\mathrm{pH}$ of the sediments seem to have a linear correlation. As the concentration of glucose injected increased, the decrease in $\mathrm{pH}$ also increased. Constant decrease in $\mathrm{pH}$ due to fermentation of glucose can be problematic (Raghavulu et al., 2009). To continually generate electricity with glucose as substrate, decrease in $\mathrm{pH}$ should be managed, because drop in $\mathrm{pH}$ would lead to decrease in electric current produced (Fig. 7).

From previous researches, it was found that interaction between fermenting bacteria and exoelectrogenic bacteria can enhance electric current generation. This research, in particular, found the importance of that relationship in sediment microorganisms. In aquatic sediment injected with glucose, Clostridium was found to have an inordinate significance in electric current generation. However, Clostridium alone cannot increase electric current production. A mutual relationship between fermenting bacteria, such as Clostridium, and exoelectrogenic bacteria, such as Geobacter, should be fulfilled in order to increase electricity production. This interaction is unique to this research in that it was found in a mixed culture of microorganisms collected from aquatic sediment. Moreover, this type of interaction was fulfilled only when a proper concentration of glucose was injected to the sediment. Further analysis of this phenomenon can significantly increase electric current produced from sediment microbial fuel cells (SMFCs). Moreover, different chemical reactions and microbial reactions to glucose injection, as verified in this research, can also attribute to increase in efficiency of sediment microbial fuel

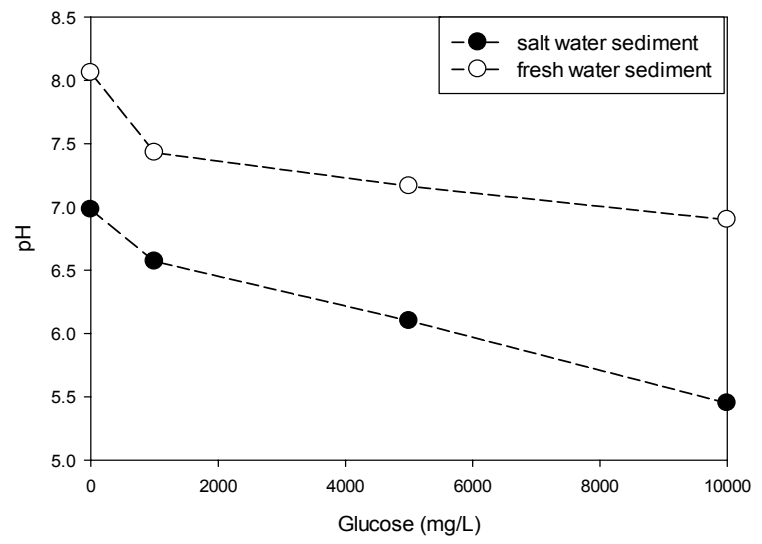

Fig. 7. $\mathrm{pH}$ of aquatic sediment. Fresh water sediment has higher $\mathrm{pH}$ than salt-water sediment. As injected molarity of glucose increases, the $\mathrm{pH}$ of sediment decreases. 
cells. If further research were conducted, more precise measurement will be discovered to increase electric current efficiency of sediment microbial fuel cells.

\section{적 요}

본 연구의 목적은 포도당을 자연의 저질기반 미생물연료전지 에 주입할 경우 전기생산을 최적화하기 위한 것이며, 이 때 관련 된 미생물의 군집을 분석하고 관련미생물의 역할을 검토하고자 하였다. $1,000 \mathrm{mg} / \mathrm{L}$ 의 포도당이 주입되었을 때 생성되는 전류가 약 3 배 가량 증가하였다. 이러한 증가는 주로 발효세균과 전기생 성세균의 상호작용에 기인하는 것으로서, 이는 발효미생물에 의 해 생성된 유기산이 전기생성 미생물에 의해서 분해되므로 유기 산의 축적을 방지하여 되먹임저해(feedback inhibition) 현상을 감소 시키는데 그 원인이 있는 것으로 보인다. 반면, 더 높은 농 도의 포도당이 주입되었을 시에는 전류가 떨어지거나 큰 증가가 일어나지 않았다. 만약 적절한 농도의 포도당이 주입될 시, 전기 생성 미생물과 발효미생물이 동시에 포도당을 분해하면서 피드 백을 제거하며 전류생성이 증가함을 알 수 있었다. 포도당을 토 양에 주입하였을 시에 Clostridium sp.과 같은 발효미생물이 많 이 나타났다. 포도당의 발효는 전기생성에 있어서 긍정적 영향 과 부정적 영향을 미칠 수 있음이 밝혀졌다. 즉 발효산물이 전기 생성미생물에 의해서 분해되어서 사용된다면 전기생성이 증가 한다. 하지만, 발효산물이 전기생성미생물에 의해서 분해되지 못한다면 여러 전기생성을 억제하는 화학적반응 $(\mathrm{pH}$ 저하, 메탄 생성, 유기산 축적 등)이 일어나고 미생물연료전지와 관계없는 미생물들이 주입된 유기물을 대부분 분해하여 전기생성이 저하 될 수 있음이 밝혀졌다. 적절한 농도의 포도당 주입을 통한 발효 세균(Clostridium sp. 등)과 전기발생균(Geobacter sp. 등)의 적 절한 조합은 자연상태에서의 혼합미생물존재 환경에서의 전기 생산을 증가시킬 수 있을 것으로 기대된다.

\section{Acknowledgements}

This work was partially supported by a National Research Foundation grant (No. 2012-0005136) from the Korean Government (MEST) and made possible by the efforts of the Manpower Development Program for Marine Energy, as part of the Ministry of Land, Transport, and Maritime Affairs (MLTM).

\section{References}

Bond, D.R. and Lovley, D.R. 2003. Electricity production by Geobactersulfurreducens attached to Electrodes. Appl. Environ. Microbiol. 69, 1548-1555.

Chin, H.L., Chen, Z.S., and Chou, C.P. 2003. Fedbatch operation using Clostridium acetobutylicum suspension culture as biocatalyst for enhancing hydrogen production. Biotechnol. Prog. 19, 383-388.

Coyne, V.E., James, M.D., Reid, S., and Rybicki, E.P. 2001. Molecular
Biology Techniques Manual, pp. 3-25. Department of Molecular and Cell Biology, University of Cape Town, South Africa.

Finch, A.S., Mackie, T.D., Sund, C.J., and Sumner, J.J. 2011. Metabolite analysis of Clostridium acetobutylicum:Fermentation in a microbial fuel cell. Biores. Technol. 102, 312-315.

Freguia, S., Rabaey, K., Yuan, Z., and Keller, J. 2008. Syntrophic processes drive the conversion of glucose in microbial fuel cell anodes. Environ. Sci. Technol. 42, 7937-7943.

He, Z., Shao, H., and Angenent, L.T. 2007. Increased power production from a sediment microbial fuel cell with a rotating cathode. Biosens. Bioelectron. 22, 3252-3255.

Holmes, D.E., Bond, D.R., and Lovley, D.R. 2004. Electron transfer by Desulfobulbus propionicus to $\mathrm{Fe}(\mathrm{III})$ and graphite electrodes. Appl. Environ. Microbiol. 70, 1234-1237.

Hong, L., Ramnarayanan, R., and Logan, B.E. 2004. Production of electricity during wastewater treatment using a single chamber microbial fuel cell. Environ. Sci. Technol. 38, 2281-2285.

Kiely, P.D., Regan, J.M., and Logan, B.E. 2011. The electric picnic: synergistic requirements for exoelectrogenic microbial communities. Curr. Opin. Biotechnol. 22, 378-385.

Logan, B.E. 2009. Exoelectrogenic bacteria that power microbial fuel cells. Nat. Rev. Microbiol. 7, 374-379.

Logan, B.E., Murano, C., Scott, K., Gray, N.D., and Head, I.M. 2005. Electricity generation from cysteine in a microbial fuel cell. Water Res. 39, 942-952.

Lovley, D.R., Giovannoni, S.J., White, D.C., Champine, J.E., Phillips, E.J.P., Gorby, Y.A., and Goodwin, S. 1993. Geobacter metallireducens gen. nov. sp. Nov., a micoorganism capable of coupling the complete oxidation of organic compounds to the reduction of iron and other metals. Arch. Microbiol. 159, 336-344.

Moon, H., Chang, I.S., and Kim, B.H. 2006. Continuous electricity production from artificial wastewater using a mediator-less microbial fuel cell. Biores. Technol. 97, 621-627.

Pant, D., Gilbert, V.B., Diels, L., and Vanbroekhoven, K. 2009. A review of the substrates used in microbial fuel cells (MFCs) for sustainable energy production. Biores. Technol. 10, 1533-1544.

Park, H.S., Kim, B.H., Kim, H.S., Kim, H.J., Kim, G.T., Kim, M., Chang, I.S., Park, Y.K., and Chang, H.I. 2011. A novel electrochemically active and $\mathrm{Fe}$ (III) reducing bacterium phylogenetically related to Clostridium butyricum isolated from a microbial fuel cell. Anaerobe 7, 297-306.

Rabaey, K., Lissens, G., Siciliano, S.D., and Verstraete, W. 2003. A microbial fuel cell capable of converting glucose to electricity at high rate and efficiency. Biotechnol. Lett. 25, 1531-1535.

Raghavulu, S.V., Mohan, S.V., Goud, R.K., and Sama, P.N. 2009. Effect of anodic $\mathrm{pH}$ microenvironment on microbial fuel cell (MFC) performance in concurrence with aerated and ferricyanide catholytes. Electrochem. Comm. 11, 371-375.

Rezaei, F., Richard, T.L., Brennan, T.L., and Logan, B.E. 2007. Substrate-enhanced microbial fuel cells for improved remote power generation from sediment-based systems. Environ. Sci. Technol.41, 4053-4058.

Schumahcer, B.A. 2002. Methods for the determination of total organic carbon (TOC) in soils and sediments, pp. 5-7. United States Environmental Protection Agency Environmental Sciences Division National Exposure Research Laboratory, Las Vegas, USA.

Song, T.-S., Yan, Z.-S., Zhao, Z.-W., and Jiang, H.-L. 2011. Construction and operation of freshwater sediment microbial fuel cell for electricity generation. Bioprocess Biosys. Eng. 34, 621-627. 